\section{Chemical constituents of the volatile oil from leaves of Annona coriacea and in vitro antiprotozoal activity}

\author{
Carlos A. T. Siqueira, ${ }^{1}$ Jocimar Oliani, ${ }^{1}$ Adilson Sartoratto, ${ }^{2}$ \\ Carmen L. Queiroga, ${ }^{2}$ Paulo R. H. Moreno, ${ }^{3}$ Juliana $Q$. \\ Reimão, ${ }^{4}$ André G. Tempone, ${ }^{4}$ Dominique C. H. Fischer ${ }^{*}, 1$
}

\begin{abstract}
${ }^{1}$ Laboratório de Farmacognosia, Departamento de Farmácia, Faculdade de Ciências Farmacêuticas, Universidade de São Paulo, Brazil,

${ }^{2}$ Divisão de Fitoquímica, Centro Pluridisciplinar de Pesquisas Químicas, Biológicas e Agrícolas, Universidade Estadual de Campinas, Brazil,

${ }^{3}$ Departamento de Química Fundamental, Instituto de Química, Universidade de São Paulo, Brazil,

${ }^{4}$ Laboratório de Toxinologia Aplicada, Departamento de Parasitologia, Instituto Adolfo Lutz, Brazil.
\end{abstract}

Revista Brasileira de Farmacognosia Brazilian Journal of Pharmacognosy 21(1): 33-40, Jan./Feb. 2011

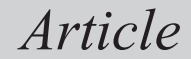

Received 6 Apr 2010 Accepted 7 Jun 2010 Available online 24 Jan 2011

Keywords: Annona coriacea Mart. Annonaceae volatile oil GC/MS-GC/FID analysis in vitro antiprotozoal activity

ISSN 0102-695X doi: 10.1590/S0102-695X2011005000004

\section{Introduction}

The alarming socio-economical reality caused by neglected diseases in Brazil and throughout the world, in special leishmaniasis and the Chagas' disease, which have presented high levels of morbidity and mortality, not to mention the limitations and toxicity of today's therapeutics, urges for new drug substances (Newman \& Cragg, 2007; Savioli, 2010; Osorio et al., 2008; Carvalho, 2009). Researches on bioactive molecules have revealed potential sources in our flora biodiversity. During the last years the Annonaceae family has been evaluated toward that (Camacho et al., 2003; Carollo et al., 2005).

Annonaceae species are widely distributed around the world (Mello-Silva \& Pontes, 2005) and are found in all the continents (Pontes et al., 2004); at a predominant way in tropical zones. This family of plants shows over 135 genera and 2500 species (Smith et al., 2004). In Brazil both tree and shrub specimens are mainly situated in the "cerrado" (Souza \& Lorenzi, 2008), the vast tropical savanna ecoregion of the country. Its main economical roles are its edible fruit production, its medicinal proprieties (Villar Del Fresno et al., 1984) and its aromatic oils extracted from several species as Cananga odorata Hook Fil. et Thomson ("ylang-ylang"), among other uses (Heywood, 1993; Judd et al., 2002).

The Annona genus, with 250 species found in the Brazilian territory (Souza \& Lorenzi, 2008; MelloSilva \& Pontes, 2005), has revealed the presence of different classes of active metabolites, like isoquinoline and pyrimidine- $\beta$-carboline alkaloids (Silva et al., 2007a, Costa et al., 2006), acetogenins (Yang et al., 2009), lectins (Coelho et al., 2003) and volatile oils (Ferreira et al., 2009; Boyom et al., 1996), against the protozoaries responsible for endemic tropical diseases.

Annona coriacea (Mart.), popularly known as "marolo", "araticum", "araticum-liso" (Hoehne, 1946; Souza \& Lorenzi, 2008), has been used as traditional medicine for treating parasitoses, ulcers and inflammation processes (Sonnet et al., 1971) and is also reported for rheumatism and as anti-helminthic (Cruz, 1985). 
The reports of isolated secondary metabolites from this species were of acetogenins (Bermejo et al., 2005; Silva et al., 1998, 1997a,b, 1996, 1995; Yu et al., 1994), diterpenoids (Onan \& Mc Phail, 1978; Orsini et al., 1977; Mussini et al.,1973a,b; Ferrari et al., 1971) and pterocarpans (Darko et al., 1983; Nakagawa et al., 1982). In our previous studies, in vitro antimalarial (Fischer et al., 2004), anti-leishmanial and trypanocidal (Tempone et al., 2005) activities were found for the crude ethanol extract and for the total alkaloids.

The antiprotozoal activity of the volatile oil from another Annona species (Costa et al., 2009) motivated this study to identify those constituents from the $A$. coriacea leaves and also to evaluate its potential anti-leishmanial and trypanocidal in vitro activities.

\section{Material and Methods}

\section{Botanical material}

Leaves from Annona coriacea Mart., Annonaceae, were collected, in October 2009, in the Estação Ecológica (Nature Reserve) of the Instituto Florestal of São Paulo, at Águas de Santa Bárbara, in São Paulo state, placed $345 \mathrm{~km}$ from the capital. The exact collecting site lies at $22^{\circ} 46^{\prime} 91^{\prime \prime}$ on the South longitude and at $49^{\circ} 14^{\prime} 40^{\prime \prime}$ on the West latitude, at an altitude of $765 \mathrm{~m}$. Voucher specimens were deposited at the Herbarium (SPF) of the Instituto de Biocienncias da Universidade de São Paulo (IB-USP), under the denomination "Siqueira-4" and were identified by the Annonaceae specialist Dr. Renato de Mello-Silva.

\section{Standard compounds}

As external reference the following standards were acquired from Fluka ${ }^{\circledR}$ (St. Louis, USA), with p.a. purity: (E)-caryophyllene and $\alpha$-humulene (sesquiterpene hydrocarbons), $\beta$-pinene (monoterpene hydrocarbon) and globulol (oxygenated sesquiterpene). A homologous series of $n$-alkanes $\left(\mathrm{C}_{9}-\mathrm{C}_{20}\right)$ was acquired from the same supplier. The standards $(0.5 \mu \mathrm{g} / \mathrm{mL})$ were diluted in $n$-hexane p.a. $\left(\right.$ Merck $\left.^{\circledR}\right)(1 \mathrm{~mL})$.

\section{Volatile oil extraction}

Fresh leaves of $A$. coriacea $(260.4 \mathrm{~g})$ were cut and hydrodistillation was carried out in a Clevengertype apparatus for $4 \mathrm{~h}$, at a temperature of $40{ }^{\circ} \mathrm{C}$. They were previously ground with solid $\mathrm{CO}_{2}$ in a blender (Ametek ${ }^{\circledR}$-36BL54) at $18000 \mathrm{rpm}$ for $3 \mathrm{~min}$. The essential oil was separated from the (frozen) water by glass capillary suction, and stored in a glass flask, protected from light and humidity, until analysis. The oil content was determined in analytical balance on a dry weight basis performed in triplicate.

\section{GC/MS and GC/FID analysis of the volatile oil}

The GC/MS volatile oil analysis was performed in the Agilent HP-6890 gas chromatograph, using a fused capillary column HP-5 MS (5\% phenylmethylpolysiloxane, J\&W Scientific) (30m x $0,25 \mathrm{~mm} \times 0,25 \mu \mathrm{m})$, directly coupled to a HP-5975 selective mass detector.

The oil injected volume was $1.0 \mu \mathrm{L}$, with split $(1: 20)$, at scan mode. The following conditions were used: temperature of injector: $220{ }^{\circ} \mathrm{C}$; temperature of GC detector: $250^{\circ} \mathrm{C}$, programmed column temperature: 60 to $250{ }^{\circ} \mathrm{C}$ at $3{ }^{\circ} \mathrm{C} / \mathrm{min}$ for $60 \mathrm{~min}$, carrier gas: helium $(1 \mathrm{~mL} / \mathrm{min}$ ). Electron impact (EI) ionization MS was used at $70 \mathrm{eV}$. Mass spectra were acquired over a range of 29-400 amu, at $1 \mathrm{scan} / \mathrm{s}$.

The retention indices for all volatile constituents were determined by co-injection of the hydrocarbon standards and the equation of Van Den Dool \& Kratz (1963) was used to calculate them. The constituents identification and the comparison of their MS data with external standard data were based on the spectrometry library of the equipment system (NIST 2005, Lib.), retention time, retention indices (RI) (Adams, 2007) and literature data (Adams, 2007; Wiley Service Co.; SciFinder Scholar, USA).

The analysis of the volatile components was carried out on HP5890 equipment under the same conditions described before. The GC system was equipped with a flame ionization detector (FID). The percentage compositions were obtained through the electronic integration of the GC peak areas without taking into account their relative response factors.

\section{In vitro antiprotozoal activity}

\section{Parasites}

The anti-leishmanial activity was evaluated against promastigotes of Leishmania (L.) chagasi (MHOM/BR/1972/LD), Leishmania (L.) amazonensis (WHO/BR/00/LT0016), Leishmania (L.) major (MHOM/1L/80/Fredlin) and Leishmania (V.) braziliensis (MHO/BR/75/M2903), cultivated in M-199 medium and supplemented with $10 \%$ calf serum and $0.25 \%$ of hemin at $24{ }^{\circ} \mathrm{C}$, without antibiotic addition. And, the trypomastigotes of Trypanosoma cruzi (strain Y) were isolated from the supernatant of LLC-MK2 (ATCC CCL 7- Rhesus monkey kidney cells) which had been previously infected with bloodstream trypomastigotes. 


\section{Anti-leishmanial activity}

The anti-leishmanial activity was determined against promastigotes of L. (L.) chagasi, L. (L.) amazonensis, L (L.) major, L. (V.) braziliensis (Sartorelli et al., 2007), using pentamidine as standard drug $(100 \mu \mathrm{g} / \mathrm{mL})$. Promastigotes were counted in a Neubauer hemocytometer and seeded at $1 \times 10^{6} \mathrm{cells} / \mathrm{well}$ in 96-well microplates and essential oil was incubated to the highest concentration of $500 \mu \mathrm{g} / \mathrm{mL}$ (based on dry weight) for $24 \mathrm{~h}$ at $24{ }^{\circ} \mathrm{C}$. Parasite viability was determined using the MTT assay at $550 \mathrm{~nm}$ (Tada et al., 1986).

Trypanocidal activity

Cell culture-derived trypomastigotes from LLC-MK2 cells were counted in a Neubauer hemocytometer and seeded at $1 \times 10^{6}$ cells/well in 96well microplates. The essential oil was incubated at the highest concentration of $500 \mu \mathrm{g} / \mathrm{mL}$ for $24 \mathrm{~h}$ at $37^{\circ} \mathrm{C}$ in a $5 \% \mathrm{CO}_{2}$ humidified incubator with benznidazole as standard drug $(100 \mu \mathrm{g} / \mathrm{mL})$. The trypomastigotes viability was based on the cellular conversion of the soluble tetrazolium salt MTT into the insoluble formazan by mitochondrial enzymes. The formazan extraction was carried out with $10 \%(\mathrm{v} / \mathrm{v})$ SDS for 18 $\mathrm{h}$ at $24{ }^{\circ} \mathrm{C}$ (Lane et al., 1996) in a spectrophotometer Multiskan MS (Uniscience) microplate reader.

\section{Statistical analysis}

The data obtained represent the mean and standard deviation of duplicate samples from two independent assays. The IC50 values were calculated using sigmoid dose-response curves in Graph $\mathrm{Pad}$ Prism 5.0 software, and the $95 \%$ confidence intervals (C.I.) are included in parenthesis. The Mann-Whitney test (unpaired two-tailed) was used for significance testing $(p<0.05)$.

\section{Results and Discussion}

The volatile oil yield from $A$. coriacea leaves was $0.05 \% \mathrm{~m} / \mathrm{m}$, compared to the dry weight of the plant material. This result was in good agreement with that found in other Annona species as: A. densicoma $(0.1 \%$ $\mathrm{m} / \mathrm{m}$ ) (Andrade et al., 2007), A. muricata $(0.0002 \%$, $0.01 \% \mathrm{~m} / \mathrm{m}$ ) (Kossouoh et al., 2007; Fournier et al., 1999), A. squamosa $(0.12 \% \mathrm{~m} / \mathrm{m})$ (Garg \& Gupta, $2005)$ and $A$. foetida $(0.01 \% \mathrm{~m} / \mathrm{m})$ (Costa et al., 2009).

The essential oil GC/MS analysis identified sixty constituents (Table 1), corresponding to $96.5 \%$ of the oil, made up of a complex mixture of sesquiterpenes (76.7\%), monoterpenes $(20.0 \%)$ and other constituents
(3.3\%). The volatile oil composition from A. coriacea showed to be in accordance with the classes of volatile constituents found in the Annona genus and in the Annonaceae family (Leboeuf et al., 1982; Lima et al., 2004; Nebié et al. 2005; Andrade et al., 2007; Fournier et al., 1999; Boyom et al., 1996).

The bicyclogermacrene sesquiterpene was the major compound (39.8\%) (Table 1). It is the precursor of spathulenol, an oxygenated sesquiterpene that was one of the main constituents found in this oil $(4.2 \%)$ (Table 1) and could be considered as a chemotaxonomic marker of the Annonaceae family, since its presence is reported in its different genera (Costa et al., 2008). The other main sesquiterpene compounds were: $\gamma$-muurolene $(7.9 \%), \quad \delta$-cadinene $\quad(6.0 \%), \quad(E)$-caryophyllene (4.9\%), spathulenol (4.2\%), $\alpha$-patchoulene $(2.7 \%)$, sesquisabinene hydrate $(2.5 \%)$ and $\alpha$-humulene $(2.4 \%)$ (Table 1).

The antifungal activity of bicyclogermacrene was previously reported (Silva et al., 2007b). Although there are no records on antiprotozoal action, its high percentage in the $A$. coriacea oil allows inferring a contribution of this compound to the revealed trypanocidal and anti-leishmanial activities. A deeper study should be conducted to confirm it. The isolation for biological testing was not possible due to the low amount of $A$. coriacea oil content.

Two other major sesquiterpenes of the $A$. coriacea oil, $\delta$-cadinene and $(E)$-caryophyllene, also showed to be frequent in the Annonaceae family (Palazzo et al., 2009), as well as $\beta$-elemene, a minor constituent $(0.7 \%)$.

(E)-caryophyllene is a marker in Annonaceae (Valter et al., 2008) and showed, together with $\delta$-cadinene, a significant activity against $L$. donovani promastigotes (Zheljazkov et al, 2008) with an IC50 of 19 and $4 \mu \mathrm{g} / \mathrm{mL}$, respectively, suggesting a probable relation to the anti-leishmanial properties of the $A$. coriacea oil (Table 2).

In the essential oil from $A$. foetida, a similar profile to that of $A$. coriacea was found as it was seen the sesquiterpenes predominance and also in relation to bicyclogermacrene and $(E)$-caryophyllene (Costa et al., 2009).

Likewise, in $A$. densicoma (Andrade et al., 2007) and A. muricata (Boyom et al., 1996), the sesquiterpenes were the greater part and in the former, the bicyclogermacrene percentage was also high $(26.8 \%)$.

When compared, A. senegalensis (Boyom et al., 1996) presented higher concentration of monoterpenes in their essential oil.

Among the other abundant sesquiterpene constituents, in the essential oil from A. coriacea, $\alpha$-humulene (2.4\%) (Table 1) has already been reported 
Table 1: Chemical composition (\%) of the volatile oil components from leaves of Annona coriacea Mart. Annonaceae.

\begin{tabular}{|c|c|c|c|c|}
\hline Constituents $^{\mathrm{a}}$ & Retention time* $(\mathrm{min})$ & $\mathrm{RI}^{\mathrm{b}}$ & $\mathrm{RI}^{\mathrm{c}}$ & $\%$ \\
\hline$\alpha$-thujene & 5.1 & 933 & 930 & 0.7 \\
\hline sabinene & 6.0 & 973 & 969 & $\operatorname{tr}$ \\
\hline$\beta$-pinene & 6.1 & 977 & 979 & 1.6 \\
\hline myrcene & 6.5 & 992 & 990 & 0.2 \\
\hline pseudolimonene & 7.6 & 1000 & 1004 & 1.6 \\
\hline$\beta$-cis-ocimene & 7.9 & 1036 & 1037 & 0.2 \\
\hline$\beta$-trans-ocimene & 8.3 & 1047 & 1050 & 0.4 \\
\hline nonanal & 10.3 & 1105 & 1100 & 0.1 \\
\hline verbenone & 14.0 & 1199 & 1205 & 0.1 \\
\hline$\beta$-cyclocitral & 14.8 & 1219 & 1219 & 0.1 \\
\hline$\delta$-elemene & 19.7 & 1335 & 1338 & 0.2 \\
\hline benzyl butanoate & 20.0 & 1344 & 1346 & 0.2 \\
\hline$\alpha$-cubebene & 20.2 & 1348 & 1348 & $\operatorname{tr}$ \\
\hline cyclosativene & 20.8 & 1362 & 1371 & 0.2 \\
\hline$\alpha$-ylangene & 21.3 & 1373 & 1375 & 1.7 \\
\hline$\beta$-bourbonene & 21.6 & 1382 & 1388 & 1.6 \\
\hline$\alpha$-isocomene & 21.8 & 1388 & 1388 & 0.4 \\
\hline$\beta$-elemene & 21.9 & 1390 & 1390 & 0.7 \\
\hline$\beta$-isocomene & 22.6 & 1406 & 1408 & 0.3 \\
\hline (E)-caryophyllene & 23.0 & 1417 & 1419 & 4.9 \\
\hline$\alpha$-guaiene & 23.4 & 1426 & 1439 & 0.4 \\
\hline gurjunene & 23.8 & 1435 & 1433 & 0.5 \\
\hline aromadendrene & 24.0 & 1441 & 1441 & 0.2 \\
\hline seychellene & 24.2 & 1447 & 1446 & 0.2 \\
\hline$\alpha$-humulene & 24.4 & 1450 & 1454 & 2.4 \\
\hline trans-prenyl limonene & 24.4 & 1452 & 1459 & 0.2 \\
\hline$\alpha$-patchoulene & 24.7 & 1457 & 1456 & 2.7 \\
\hline ageratochromene 6-dimethoxy & 24.9 & 1463 & 1463 & 0.4 \\
\hline carota-1,4-diene & 25.2 & 1471 & 1472 & 0.2 \\
\hline 10- $\beta$-h-cadina- $1,6,4$-diene & 25.4 & 1475 & 1476 & 0.7 \\
\hline$\gamma$-muurolene & 25.5 & 1479 & 1479 & 7.9 \\
\hline$\alpha$-amorphene & 25.7 & 1483 & 1484 & 0.1 \\
\hline trans- $\beta$-ionone & 25.8 & 1485 & 1488 & 0.4 \\
\hline$\beta$-selinene & 25.9 & 1489 & 1490 & 0.2 \\
\hline bicyclogermacrene & 26.3 & 1497 & 1500 & 39.8 \\
\hline aciphyllene & 26.5 & 1503 & 1501 & 0.6 \\
\hline$\delta$-amorphene & 26.8 & 1511 & 1512 & 0.6 \\
\hline$\delta$-cadinene & 27.2 & 1522 & 1523 & 6.0 \\
\hline zonarene & 27.5 & 1529 & 1529 & $\operatorname{tr}$ \\
\hline$\alpha$-calacorene & 27.9 & 1540 & 1540 & 0.1 \\
\hline selina-3,7-11-diene & 28.2 & 1548 & 1546 & $\operatorname{tr}$ \\
\hline eremophila ketone & 28.8 & 1563 & 1560 & 0.3 \\
\hline cis-3-hexenyl benzoate & 29.0 & 1569 & 1566 & 0.1 \\
\hline spathulenol & 29.2 & 1574 & 1578 & 4.2 \\
\hline sesquisabinene hydrate & 29.4 & 1580 & 1579 & 2.5 \\
\hline globulol & 29.7 & 1588 & 1590 & 1.0 \\
\hline
\end{tabular}


Table 1: Chemical composition (\%) of the volatile oil components from leaves of Annona coriacea Mart. Annonaceae (cont.).

\begin{tabular}{|c|c|c|c|c|}
\hline viridiflorol & 29.8 & 1590 & 1592 & 0.3 \\
\hline rosifoliol & 30.1 & 1598 & 1600 & 0.8 \\
\hline ethanone & 30.4 & 1605 & 1607 & 0.2 \\
\hline$\beta$-oplopenone & 30.5 & 1608 & 1607 & 0.3 \\
\hline $4 \mathrm{a}(2 \mathrm{~h})$-naphthalenol & 31.1 & 1625 & 1631 & 0.6 \\
\hline isocedrenone & 31.3 & 1631 & 1631 & $\operatorname{tr}$ \\
\hline alloaromadendrene epoxide & 31.5 & 1635 & 1641 & 0.9 \\
\hline$\alpha$-epi-cadinol & 31.6 & 1638 & 1640 & 1.4 \\
\hline hisenol & 31.8 & 1643 & 1641 & 0.5 \\
\hline$\beta$-eudesmol & 31.9 & 1646 & 1650 & 1.1 \\
\hline$\alpha$-eudesmol & 32.0 & 1649 & 1653 & 1.0 \\
\hline$\alpha$-cadinol & 32.1 & 1651 & 1654 & 1.6 \\
\hline$\alpha$-betulenol & 32.6 & 1666 & 1667 & 0.3 \\
\hline khusinol & 33.2 & 1682 & 1680 & 0.3 \\
\hline
\end{tabular}

adentification by comparison with GC/MS spectra and RI with the internal NIST library and with Adams (2007), RI ${ }^{\mathrm{b}}$ (retention index) obtained on a capillary column HP-5MS based on $n$-alkane series and calculated following Van Der Dool e Kratz (1963), RI': according to Adams (2007), ${ }^{*}$ :on HP-5MS, tr: traces $(<0.1 \%)$

Table 2. In vitro activity of Annona coriacea Mart. against promastigotes of Leishmania (L.) amazonensis (WHO/BR/00/LT0016), L. (V.) braziliensis (MHO/BR/75/M2903) L. (L.) chagasi (MHOM/BR/1972/LD) e L. (L.) major (MHOM/1L/80/Fredlin) and against trypomastigotes of Trypanosoma cruzi (strain Y).

\begin{tabular}{lccccc}
\hline \multicolumn{5}{c}{ IC50 $(\mu \mathrm{g} / \mathrm{mL})(95 \%$ C.I. $)$} \\
promastigotes
\end{tabular}

IC50: inhibitory concentration of 50\% parasites; $95 \%$ C.I. $=$ confidence interval, *up to $500 \mu \mathrm{g} / \mathrm{mL}, * * 100 \mu \mathrm{g} / \mathrm{mL}$.

in A. senegalensis (Nebié et al., 2005; Lima et al., 2004)

In what concerns the monoterpene constituents of the oil, the majority presented a percentage lower than $1 \%$ and were non-oxygenated (91.7\%). The most abundant compounds were $\beta$-pinene (1.6\%) and pseudolimonene (1.6\%) (Table 1).

In contrast, although the sesquiterpenes of the volatile oil from $A$. foetida had been the main compounds similarly to that from $A$. coriacea, monoterpenes were not in its composition (Costa et al., 2009).

The trypanocidal activity against $T$. cruzi trypomastigotes was ascribed before to the oxygenated monoterpenes of the volatile oil from Cymbopogum citratus (Santoro et al., 2007). And, although they are in lower proportion in the A. coriacea oil, it is likely that they are related to the activity (IC50 $168.50 \mu \mathrm{g} /$ $\mathrm{mL})(95 \%$ C.I. $99.10-286.60 \mu \mathrm{g} / \mathrm{mL})$ of its other constituents, in a synergic behavior (Table 2). The same authors related this activity to the process of rupture of the cell wall, with the extravasations of the cytoplasm and of the nucleus of the parasite.

Likewise, researches have attributed to the oxygenated sesquiterpenes the activity against different species of Leishmania (Arruda et al., 2005). In $A$. coriacea, these constituents represent $39.1 \%$ of the sesquiterpene compounds found in its oil. Possibly, also a synergic action with the oxygenated monoterpenes caused the leishmanicidal action verified against the four species of Leishmania, in this study (Table 2 ), even considering the lower percentage related to monoterpenes. However more investigations are 
required to know better the real mechanisms of action of the essential oils.

L. (L.) chagasi was the most sensible specie to the volatile oil from $A$. coriacea (IC50 39.93 $\mu \mathrm{g} / \mathrm{mL}$ ) (95\% C.I.: $28.00-56.95 \mu \mathrm{g} / \mathrm{mL}$ ) (Table 2). A similar behavior was observed against the same protozoa with the $A$. foetida oil (IC50 $27.2 \mu \mathrm{g} /$ $\mathrm{mL}$ ) (Costa et al., 2009). Meanwhile, against the other two same Leishmania species, the volatile oil from $A$. foetida was more active than this of $A$. coriacea. Therefore, against L. (V.) braziliensis and $L$ (L.) amazonensis parasites, the $A$. coriacea and $A$. foetida IC50 were, respectively: 261.20 (95\% C.I.: $179.50-380.10 \mu \mathrm{g} / \mathrm{mL}) ; 9.9 \mu \mathrm{g} / \mathrm{mL}$ and 160.20 (95\% C.I.: $117.70-218.10 \mu \mathrm{g} / \mathrm{mL}) ; 16.2$ $\mu \mathrm{g} / \mathrm{mL}$.

This work is the first report of the volatile oil analysis from $A$. coriacea and contributed to improve the knowledge about this species and its genus, still little has been known in this respect. The chemosystematic markers of the Annonaceae family and of the genus were found in this Annona for the first time, being of importance for future researches. Since its antiprotozoal activity was confirmed, the species can be seen as a potential source of antiprotozoal molecules to be searched in further studies.

\section{Acknowledgments}

The authors are grateful to FAPESP and CAPES for the grant and fellowship.

\section{References}

Adams RP 2007. Identification of essential oil components by gas chromatography/mass spectrometry. Carol Stream: Allured Publ.

Andrade EHA, Oliveira J, Zoghbi MGB 2007. Volatiles of Anaxagorea dolichocarpa Spreng. \& Sandw. and Annona densicoma Mart. growing wild in the State of Pará, Brazil. Flavour Fragrance J 22: 158-160.

Arruda DC, D’Alexandri FL, Katzin AM, Uliana SRB 2005. Antileishmanial activity of the terpene nerolidol. Antimicrob Agents Chemother 49: 1679-1687.

Bermejo A, Figadère B, Zafra-Polo $\mathrm{MC}$, Barrachina I, Estornell E, Cortes D 2005. Acetogenins from Annonaceae: recent progress in isolation, synthesis and mechanisms of action. Nat Prod Rep 22: 269303.

Boyom FF, Zollo PHA, Menut C, Lamaty G, Bessière JM 1996. Aromatic plants of tropical Central Africa. Part XXVII. Comparative study of the volatile constituents of five Annonaceae species growing in Cameroon. Flavour Fragrance J 11: 333-338.

Camacho MDR, Phillipson JD, Croft SL, Solis PN,
Marshall SJ, Ghazanfar SA 2003. Screening of plant extracts for antiprotozoal and cytotoxic activities. $J$ Ethnopharmacol 89: 185-191.

Carollo CA, Hellmann AR, Máximo de Siqueira J 2005. Sesquiterpenoids from the essential oil from leaves of Duguetia furfuracea (Annonaceae). Biochem Syst Ecol 33: 647-649.

Carvalho PL 2009. A proteção da biodiversidade brasileira: o caso das plantas medicinais. http://www.infobibos. com/Artigos/2009_2/Biodiversidade/index.htm. Access June 2010.

Coelho MB, De Souza IA, Freire MGM, Marangoni S, Antunes E, Macedo MLR 2003. Neutrophil migration in mice induced by a mannose-binding lectin isolated from Annona coriacea seeds. Toxicon 48: 529-535.

Costa EV, Pinheiro MLB, Silva JRA, Maia BHLNS, Duarte MCT, Amaral ACF, Machado GMC, Leon LL 2009. Antimicrobial and antileishmanial activity of essential oil from leaves of Annona foetida (Annonaceae). Quim Nova 32: 78-81.

Costa EV, Pinheiro MLB, Xavier CM, Silva JRA, Amaral ACF, Souza ADL, Barison A, Campos FR, Ferreira AG, Machado GMC, Leon LLP 2006. A pyrimidine$\beta$-carboline and other alkaloids from Annona foetida with antileishmanial activity. J Nat Prod 69: 292294.

Costa EV, Teixeira SD, Marques FA, Duarte MCT, Delarmelina C, Pinheiro MALB, Trigo JR, Sales Maia BHLN 2008. Chemical composition and antimicrobial activity of the essential oils of the Amazon Guatteriopsis species. Phytochemistry 69: 1895-1899.

Cruz GL 1985. Dicionário de plantas úteis do Brasil. 3 ed. Rio de Janeiro: Civilização Brasileira.

Darko LL, Nakanishi K, Nakagawa M 1983. Physiologically active pterocarpan compounds, their isolation and therapeutically active compositions containing them. Eur Pat Appl EP 0,089,229. apud SciFinder Scholar.

Ferrari M, Pelizzoni F, Ferrari G 1971. New diterpenoids with clerodane skeleton. Phytochemistry 10: 3267-3269.

Ferreira L, Perestrelo R, Camara JS 2009. Comparative analysis of the volatile fraction from Annona cherimola Mill. cultivars by solid-phase microextraction and gas chromatography-quadrupole mass spectrometry detection. Talanta 77: 1087-1096.

Fischer DCH, Gualda NCA, Bachiega D, Carvalho CS, Lupo FN, Bonoto SV, Alves MO, Yogi A, Di Santi SM, Ávila PE, Kirchgatter K, Moreno PRH 2004. In vitro screening for antiplasmodial activity of isoquinoline alkaloids from Brazilian plant species. Acta Trop 92: 261-266.

Fournier G, Leboeuf M, Cave A 1999. Annonaceae essential oils: a review. J Essent Oil Res 11: 131-142.

Garg SN, Gupta D 2005. Composition of the leaf oil of Annona squamosa L. from the North Indian plains. J Essent Oil Res 17: 257-258. 
Heywood VH (ed.) 1993. Flowering plants of the world. Oxford: University Press, p.30-31.

Hoehne FC 1946. Frutas indígenas. São Paulo: Instituto de Botânica.

Judd W, Campbell CS, Kellog EA, Stevens PF, Donogahue MJ 2002. Plant systematics: a phylogenetic approach. 2.ed. Sunderland: Sinauer, p.576.

Kossouoh C, Moudachirou M, Adjakidje V, Chalchat JC, Figuérédo G 2007. Essential oil chemical composition of Annona muricata L. leaves from Benin. J Essent Oil Res 19: 307-309.

Lane JE, Ribeiro-Rodrigues R, Suarez CC, Bogitsh BJ, Jones MM, Singh PK, Carter CE 1996. In vitro trypanocidal activity of tetraethylthiuram disulfide and sodium dietylamine-N-carbodithioate on Trypanosoma cruzi. Am J Trop Med Hyg 55: 263-266.

Leboeuf M, Cave A, Bhaumik PK, Mukherjee B, Mukherjee $\mathrm{R}$ 1982. The phytochemistry of the Annonaceae. Phytochemistry 21: 2783-2813.

Lima MA, Barbosa-Filho JM, Merlic CA, Doroh BC, Maia JGS, Silva MS, Cunha EVL 2004. Alkaloids and volatile constituents from Guatteria poeppigiana. Biochem Syst Ecol 32: 347-349.

Mello-Silva R, Pontes AF 2005. Annonaceae do Parque Nacional da Serra da Canastra, Minas Gerais, Brasil. Bol Bot Univ. São Paulo 23: 71-84.

Mussini P, Orsini F, Pelizzoni F, Buckwalter BL, Wenkert E 1973a. Carbon-13 nuclear magnetic resonance spectroscopy of naturally occurring substances. XXII. Carbon-13 configuration of annonalide. Tetrahedron Lett 49: 4849-4851.

Mussini P, Orsini F, Pelizzoni F, Ferrari G 1973b. Constituents of Annona coriacea: structure of a new diterpenoid. $J$ Chem Soc, Perkin Trans I: 2551-2557.

Nakagawa M, Nakanishi K, Darko LL, Vick JA 1982. Structures of cabenegrins A-I and A-II, potent antisnake venoms. Tetrahedron Lett 23: 3855-3858.

Nebié RHC, Yaméogo RT, Bélanger A, Sib SF 2005. Chemical composition of leaf essential oil of Annona senegalensis Pers. from Burkina Faso. J Essent Oil Res 17: 331-332.

Newman DJ, Cragg GM 2007. Natural products as sources of new drugs over the last 25 years. $J$ Nat Prod 70: 461-477.

NIST 2005. NIST/EPA/HIH Mass Spectral Library, NIST Mass Spectral Search Program (NIST 05). Version 2.0d. Gaithersburg: NIST Mass Spectrometry Data Center.

Onan KD, McPhail AT 1978. Crystal and molecular structure of annonalide, a $9 ß \mathrm{H}$-pimaradienic diterpenoid from Annona coriacea. J Chem Res, Synop 1: 15.

Orsini F, Pellizoni F, McPhail AT, Onan KD, Wenkert E 1977. The structure of annonalide. Tetrahedron Lett 12: 1085-1088

Osorio EJ, Robledo SM, Bastida J 2008. Alkaloids with antiprotozoal activity: chapter 2. Alkaloids: Chem Biol 66: 113-190.

Palazzo MC, Wright HL, Agius BR, Wright BS, Moriarity DM, Haber WA, Setzer WN 2009. Chemical compositions and biological activities of leaf essential oils of six species of Annonaceae from Monteverde, Costa Rica. Rec Nat Prod 3: 153-160.

Pontes AL, Barbosa MRV, Maas PJM 2004. Flora paraibana: Annonaceae Juss. Acta Bot Brasilica 18: 281-293.

Santoro GF, Cardoso MG, Guimaraes LGL, Freire JM, Soares MJ 2007. Anti-proliferative effect of the essential oil of Cymbopogon citratus (DC) Stapf (lemongrass) on intracellular amastigotes, bloodstream trypomastigotes and culture epimastigotes of Trypanosoma cruzi (Protozoa: Kinetoplastida). Parasitology 134: 16491656.

Sartorelli P, Andrade SP, Melhem MSC, Prado FO, Tempone AG 2007. Isolation of antileishmanial sterol from the fruits of Cassia fistula using bioguided fractionation. Phytother Res 21: 644-647

Savioli L 2010. Neglected tropical diseases. http://www. who.int/neglected_diseases/director/en/index.html. Access June 2010.

Silva DB, Matos MFC, Nakashita ST, Misu CK, Yoshida NC, Carollo CA, Fabri JR, Miglio HS, Siqueira JM 2007. Isolamento e avaliação da atividade citotóxica de alguns alcalóides oxaporfínicos obtidos de Annonaceae. Quim Nova 30: 1809-1812.

Silva ELM, Roblot F, Hocquemiller R, Serani L, Laprevote O 1998. Structure elucidation of annoheptocins, two new heptahydroxylated C37 acetogenins by highenergy collision-induced dissociation tandem mass spectrometry. Rapid Commun Mass Spectrom 12: 1936-1944.

Silva ELM, Roblot F, Laprévote O, Sérani L, Cave A 1997a. Coriaheptocins $\mathrm{A}$ and $\mathrm{B}$, the first heptahydroxylated acetogenins, isolated from the roots of Annona coriacea. J Nat Prod 60: 162-167.

Silva ELM, Roblot F, Laprevote O, Varenne P, Cave, A 1995. Acetogenins from Annonaceae. Part 40. Coriacin and 4-deoxycoriacin, two new mono-THF acetogenins from the roots of Annona coriacea. Nat Prod Lett 7: 235-242.

Silva ELM, Roblot F, Mahuteau J, Cave A 1996. Coriadienin, the first Annonaceous acetogenin with two double bonds isolated from Annona coriaceae. J Nat Prod 59: 528-530.

Silva L, Oniki GH, Agripino DG, Moreno PRH, Young MCM, Mayworm MAS, Ladeira AM 2007. Bicyclogermacrene, resveratrol e atividade antifúngica em extratos de folhas de Cissus verticullatta (L.) Nicolson \& Jarvis (Vitaceae). Rev Bras Farm 17: 361-367.

Silva, ELM, Roblot F, Cave A 1997b. Acetogenin from Annonaceae. 57. Coriacyclodienin and coriacycloenin: 
two new annonaceous acetogenins from Annona coriacea. Heterocycles 45: 915-925.

Smith N, Mori SA, Henderson A, Stevenson DW, Heald SV (eds.) 2004. Flowering plants of the Neotropics. Princeton: Princeton University Press, p.18.

Sonnet PE, Jacobson M 1971. Tumor inhibitors. II. Cytotoxic alkaloids from Annona purpurea. J Pharm Sci 60: 1254-1256.

Souza VC, Lorenzi H 2008. Botânica sistemática: guia ilustrado para identificação das famílias de Fenerógamas nativas e exóticas no Brasil, baseado em APG II. 2.ed. Nova Odessa: Instituto Plantarum.

Tada H, Shiho O, Kuroshima K, Koyama M, Tsukamoto $\mathrm{K}$ 1986. An improved colorimetric assay for interleukin-2. J Immunol Methods 93: 157-165.

Tempone AG, Treiger Borborema SE, Andrade Jr HF, Amorim Gualda NC, Yogi A, Salerno Carvalho C, Bachiega D, Lupo FN, Bonotto SV, Fischer DCH 2005. Antiprotozoal activity of Brazilian plant extracts from isoquinoline alkaloid-producing families. Phytomedicine 12: 382-390.

Valter JL, Alencar KMC, Sartori ALB, Nascimento EA, Chang R, Morais SAL, Laura VA, Yoshida NC, Carollo CA, Silva DB, Grassi RF, Fabri JR, Siqueira JM 2008. Variação química no óleo essencial das folhas de seis indivíduos de Duguetia furfuracea (Annonaceae). Rev Bras Farmacogn 18: 373-378.

Van Den Dool H, Kratz PD 1963. A generalization of the retention index system including linear temperature programmed gas-liquid partition chromatography. $J$ Chromatogr 11: 463-471.

Villar Del Fresno A, Mares Arambul M, Rios Canavate JL 1984. Propriétés antimicrobiennes des feuilles d'Annona cherimolia Mill. Plant Med Phytother 17: 230-235.

Savioli L 2010. http://www.who.int/neglected_diseases/ director/en/index.html, access June 2010.

Yang H, Li X, Tang Y, Zhang N, Chen J, Cai B 2009. Supercritical fluid $\mathrm{CO}_{2}$ extraction and simultaneous determination of eight annonaceous acetogenins in Annona genus plant seeds by HPLC-DAD method. $J$ Pharm Biomed Anal 49: 140-144.

Yu JG, Hu, XE, Ho DK, Bean MF, Stephens RE, Cassady, JM, Brinen, LS, Clardy J 1994. Absolute stereochemistry of (+)-gigantecin from Annona coriacea (Annonaceae) J Org Chem 59: 1598-1599.

Zheljazkov VD, Cantrell CL, Tekwani B, Khan SI 2008. Content, composition, and bioactivity of the essential oils of three basil genotypes as a function of harvesting. J Agric Food Chem 56: 380-385

\section{*Correspondence}

Dominique C. H. Fischer

Laboratório de Farmacognosia, Departamento de Farmácia,
Faculdade de Ciências Farmacêuticas, Universidade de São Paulo

Av. Professor Lineu Prestes 580, 05508-000 São Paulo-SP, Brazil

domi@usp.br

Tel.+55 1130913658

Fax: +55 1138154418 . 